\title{
A Project Approach to Enterprise Resource Planning Implementation
}

\author{
Michael F. Frimpon ${ }^{1}$ \\ ${ }^{1}$ Ghana Institute of Management and Public Administration (GIMPA), Ghana \\ Correspondence: Michael F. Frimpon, Ghana Institute of Management and Public Administration (GIMPA), \\ Ghana. Tel: 233-20-250-4498. E-mail: mfrimpon@gimpa.edu.gh
}

Received: January 19, 2012 Accepted: March 22, 2012 Online Published: May 16, 2012

doi:10.5539/ijbm.v7n10p116

URL: http://dx.doi.org/10.5539/ijbm.v7n10p116

\begin{abstract}
An Enterprise Resource Planning (ERP) implementation process is a complex programming initiative with an overabundance of influencing factors that can shape its success. This paper has 2 objectives to: (I) use simple project management tools and techniques to restructure the implementation process in order to reduce the complexity (II) build a stable model that will be largely insensitive to minor perturbations.

The 28 Critical Success Factors (CSFs) used in this model are partitioned into 5 special groups called roles. The restriction of the interactions to within roles resulted in a reduction of pairwise comparisons between CSFs from 378 in the unstructured process to 79 in the model. Pairwise comparisons are a measure of complexity. In addition, the rate of change of pairwise comparisons reduced from 29 in the unstructured process to a maximum of 9 and as low as 5 in the model.
\end{abstract}

Keywords: Enterprise Resource Planning (ERP), Critical Success Factors (CSFs), roles, pair-wise comparisons, Project Management (PM), perturbations

\section{Background}

In fundamental terms, ERP is an integrated software package consisting of a set of standard functional modules (production, sales, human resources, finance, etc.) developed or integrated by the vendor that can be adapted to the specific needs of each customer (Esteves-Sousa et al, 2000).

To be considered an ERP system, a software package must provide the function of at least two systems. For example, a software package that provides both payroll and accounting functions could technically be considered an ERP software package (Maheshwari et al, 2011).

Modern ERP was introduced by research and analysis firm Gartner in 1990. The market for ERP was boosted by the $\mathrm{Y} 2 \mathrm{~K}$ problem. In the years leading up to the new millennium, business and industry began to realize they had a huge problem on their hands: Y2K. Research discussing the anticipated Y2K crash and efforts to forego any data loss highlights how many companies investigated new data management software to replace their outdated legacy systems before January 1, 2000. This new software need led to the market growth for ERP software, designed to replace legacy systems and envelope all facets of a business under one software "umbrella" (Maheshwari et al, 2011).

\subsection{Definition}

An ERP process involves an overabundance of factors that impact the implementation to varying degrees. Table 1 (in appendix) shows a listing with full description of the CSFs sifted from other publications that was used in this paper. A factor that is critical to the success of the process is intuitively referred to as a Critical Success factor (CSF). About $81.5 \%$ of the variation in the ERP systems implementation can be explained by the CSFs (Colmenares, Copyright $@$ ( 2009, IGI Global). Therefore, CSFs are factors that are fundamental to the success of the implementation, and an organization must handle these CSFs well in order to have a successful implementation. 
Table 1. Compilation of CSFs with associated Descriptions

\begin{tabular}{|c|c|c|}
\hline \# & $\mathrm{CSF}$ & DESCRIPTION \\
\hline \multirow[t]{2}{*}{1} & $\begin{array}{l}\text { Vision and } \\
\text { Goals }\end{array}$ & $\begin{array}{l}\text { Goals should be clearly defined and well-understood (Shanks et al., 2000). Attaining } \\
\text { stated goals or benefits is important to sustaining organizational commitment to ERP } \\
\text { implementation (NAH). A good business vision is helpful because it reduces the effort } \\
\text { of capturing the functionality of the ERP business model and therefore minimizes the } \\
\text { customization effort (Esteves). }\end{array}$ \\
\hline & & $\begin{array}{l}\text { Visioning and planning requires articulating a business vision to the organization, } \\
\text { identifying clear goals and objectives, and providing a clear link between business } \\
\text { goals and IS strategy (Finney). }\end{array}$ \\
\hline 2 & ERP Version & $\begin{array}{l}\text { The choice of the correct ERP version has to be decided upon. An older version may } \\
\text { result in frequent updating (Esteves). This is especially true in Africa where the } \\
\text { tendency is for officials to purchase the most outmoded software and other products } \\
\text { from China and the West. }\end{array}$ \\
\hline \multirow[t]{2}{*}{3} & ERP Strategy & $\begin{array}{l}\text { This includes management decisions concerning how the software package is to be } \\
\text { implemented (Holland et al, 1999). There are different approaches to ERP } \\
\text { implementation strategy ranging from 'phased' to 'big-bang' implementations (Gibson } \\
\text { et al, 1997). While 'phased' implementations provide usable functionality } \\
\text { incrementally, 'big-bang' ones offer full functionality all at once at implementation end. } \\
\text { (Esteves) }\end{array}$ \\
\hline & & $\begin{array}{l}\text { Other researchers have addressed the question of whether the implementation should be } \\
\text { centralized versus decentralized (Siriginidi, 2000a, b). Also there is the benefit of } \\
\text { introducing a new system and completely forgetting about the legacy system. This is } \\
\text { called the greenfield site, as opposed to a brownfield site (Finney). The Greenfield site } \\
\text { concept was considered during the search for a new ERP for GIMPA. }\end{array}$ \\
\hline \multirow[t]{2}{*}{4} & $\begin{array}{l}\text { Management } \\
\text { Support }\end{array}$ & $\begin{array}{l}\text { Management support is important for accomplishing project goals and objectives and } \\
\text { aligning these with strategic business goals (Sumner 1999). Sustained management } \\
\text { commitment, both at top and middle levels during the implementation, in terms of their } \\
\text { own involvement and the willingness to allocate valuable organizational resources } \\
\text { (Holland et al. 1999). }\end{array}$ \\
\hline & & $\begin{array}{l}\text { It has been empirically proven that strong and committed leadership at the top } \\
\text { management level is essential to the success of an ERP implementation (Finney). }\end{array}$ \\
\hline 5 & $\begin{array}{l}\text { Decision } \\
\text { Delegation }\end{array}$ & $\begin{array}{l}\text { Project team members must be empowered to make quick decisions to reduce delays in } \\
\text { implementation related with slow decision- making (Parr et. al, 1999). Organizations } \\
\text { should attempt to make decisions as rapidly as possible, as even small delays can have } \\
\text { an impact on such a long-term project (De Bruin, 1997). }\end{array}$ \\
\hline \multirow[t]{2}{*}{6} & $\begin{array}{l}\text { Project } \\
\text { Champion }\end{array}$ & $\begin{array}{l}\text { This individual is considered to be central to successful implementations is that he has } \\
\text { both the position and the skills that are critical to handle organizational change (Parr et } \\
\text { al. 1999). The role of the project champion is very important for marketing the project } \\
\text { throughout the organization (Sumner, 1999). The champion is really an ERP project } \\
\text { advocate. }\end{array}$ \\
\hline & & $\begin{array}{l}\text { The individual should possess strong leadership skills, as well as business, technical } \\
\text { and personal managerial competencies (Finney). }\end{array}$ \\
\hline 7 & $\begin{array}{l}\text { Hardware and } \\
\text { Software }\end{array}$ & $\begin{array}{l}\text { Suitability of software and hardware is one of } 10 \text { critical factors of Singhal. } \\
\text { Management must make a careful choice of an ERP package that best matches the } \\
\text { legacy systems, e.g. the hardware platform, databases and operating systems. The } \\
\text { suitability of software and hardware refers to the fit between the selected ERP system } \\
\text { and the hardware. Lack of data software quality and reliability and the hardware, } \\
\text { software difficulties lead to ERP failure (Shruti). }\end{array}$ \\
\hline 8 & Data Accuracy & $\begin{array}{l}\text { Data loaded from existing legacy systems must be of high quality [1].(Shanks), Data } \\
\text { must be cleansed and transferred to the ERP system to ensure no disruption to } \\
\text { performance, high quality data is very important in the integrated environment of an } \\
\text { ERP system. }\end{array}$ \\
\hline
\end{tabular}


9 Configuration Configuring the software and making it actually useful to the business is an aspect of ERP implementation that no business manager is ever willing to face (Shruti). Serious attention should be given to the conference room pilot (CRP), which provides a demonstration of the ERP system that users can test drive before the system configuration is locked down. The system should not be under configured. It can become a nightmare to spend many months designing and building a system, just to have it perform slowly out of the gate (Swartz).

10 Performance Milestones and targets need to be actively monitored to track the progress of an ERP Monitoring and project (Murray \& Coffin, 2001; Roberts \& Barrar, 1992; Rosario, 2000; Sumner, Evaluation 1999). Roberts and Barrar (1992) indicated that two criteria may be used: (a) project management-based criteria should be used to measure against completion dates, costs, and quality and (b) operational criteria should be used to measure against the production system (NAH). According to Majed Al-Mashari et al, the measuring and evaluation of performance are very critical factors in ensuring the success of any organization (Yingjie). Preventive maintenance is related with the problem and risk areas that exist in every implementation. Trouble-shooting mechanisms should be included in the implementation plan.

11 Testing and Troubleshooting errors is critical (Holland et al., 1999). Rigorous and sophisticated Troubleshooting software testing eases implementation (Rosario, 2000). Development and testing perspectives unique to ERP projects must be well-thought-out and managed (NAH).

12 Customization Even the most robust out-of-the-box ERP functionality might need to be customized to fit the business. The possibilities of such customizations should be addressed upfront versus during mid-deployment, in order to have better control over the costs.

The management of the tradeoffs between customization and standardization is a key to a successful implementation.

13 Consultant Support

Although universities have usually restricted budgets, external consultants cannot be replaced and play an essential role in the implementation process. Considering the particularities of the university staff an advantage could be obtained by the quick and substantial transfer of knowledge from consultants to qualified university staff, creating the possibility for them to participate to the tasks of external consultants or even to take them over (Ramona). In fact, it is imperative to arrange for knowledge transfer from the consultant to the company so as to decrease the dependency on the vendor/consultant (Finney).

14 Vendor Support Just like China in the early 2000s, most of Ghana's companies purchase ERP packages from foreign ERP vendors (IDC 1998) and ERP represent the best-practice processes that is different from Ghana's organizational business process, thus, it's important to get the vendor's support. Software vendors should be carefully selected since they play a crucial part in shaping the ultimate outcome of the implementation.

15 Standardization Organizations should be willing to change their businesses to fit the software in order to / Vanilla ERP minimize the degree of customizations needed (Bingi, Sharma, \& Godla, 1999; Holland et al., 1999; Murray \& Coffin, 2001; Roberts \& Barrar, 1992; Shanks et al., 2000). Wherever and as far as possible, the ERP-hosting organization should try to adopt the processes and options built into the ERP, rather than seek to modify the ERP to fit the particular business practices (Parr et al, 1999). The concept of vanilla ERP means that organizations should be committed to the idea of implementing the unadulterated or basic version with no or minimal customization (Finney). That is the ultimate in standardization.

16 User Involvement

A major cause of ERP failure is lack of employee involvement (Barker \& Frolick, 2003). User involvement and participation will result in a better fit of user requirements achieving better system quality, use and acceptance. Statistical results show that lack of end user involvement can cause the ERP process to have difficulties (Lee et al.) User participation refers to the behaviors and activities that users perform in the system implementation process. User involvement refers to a psychological state of the 
individual, and is defined as the importance and personal relevance of a system to a user (Hartwick and Barki 1994). User involvement and participation will result in a better fit of user requirements achieving better system quality, use and acceptance.

17 Organizational Culture

Culture has a substantial and definite influence on organizations, organizational behavior, and the management of organizations. Many difficulties have been faced when implementing and using western technologies, management processes, information systems methods, and information systems techniques in developing countries (Shanks).

Enterprise-wide culture and structure change should be managed (Falkowski et al., 1998), which includes people, organization, and culture change (Rosario, 2000). A culture with shared values and a strong corporate identity that is conducive to change is critical (NAH). In the local context, the mentality change from using reams of paper to electronic media should be encouraged, and ERP facilitates that.

18 Education and The most measured subset of costs is the initial software development efforts while the Training most uncertain (and often the largest) cost is long-term maintenance and training (Hubbard, Samuelson). Users can only gain an appreciation of the utility of the system only if they are well trained to use it. Insufficient training causes significant negative impact on ERP systems implementation (Lee)

19 Discipline Ensuring that a complex change like that associated with a transcendental information system that gets the right results, in the right timeframe, at the right costs, requires a paradigm change in an attitude as basic as discipline. This can be improved through indoctrination at meetings to address attitudinal changes.

Wilson et al (1994) claims that ERP packages, lack of top management support, changes in personnel, lack of discipline, resistance, and lack of broad-based company commitment are the major factors that slow down the process of implementation (Zhang).

20 Commitment Sustained management commitment, both at top and middle levels during the implementation, in terms of their own involvement and the willingness to levels during the implementation, in terms of their own involvement and the willingness to allocate valuable organizational resources (Holland et al. 1999). The need for organizational commitment should be stressed during strategy sessions because a lax in that can scupper the project.

21 Needs assessment One of the first steps involves evaluating the needs and requirements that will drive the implementation of an ERP system. A needs assessment with a definition of requirements is essential not only to guide the start of the project, but also to gauge the success of the project after completion. The basic description of needs should be refined to a set of specific institutional acceptance criteria at an early phase of the project. This statement will be used at a later date to help evaluate the success of the project in meeting these goals (Swartz)

22 Staffing A dedicated and competent staff is a must. Esteves lists this factor as one of the critical success facts. Furthermore, Sumner (1999) examined the relationship between critical success factors (CSFs) and ERP system performance, and among the CSFs identified was, maintaining excellent staffing (Wen-Hsien Tsai et al.)

23 Team ERP projects typically require some combination of business, information technology, Composition vendor, and consulting support. The structure of the project team has a strong impact in the implementation process. Two important factors are the integration of third-party consultants within the team and the retention within the organization of the relevant ERP knowledge (Esteves et al.)

24 Formalized Plan A single integrated project plan, not a collection of independent plans that can't be rolled into a summary report to management (Swartz). This means to have a well-defined plan/schedule for all the activities involved in the ERP implementation, with an appropriate allocation of budget and resources for these activities. Evidence shows that the majority of projects fail to finish the activities on time and within budget. (Esteves) 
25 Coordination Good coordination and communication between implementation partners are essential (NAH).

According to Dennis Lock (1996), "project management has evolved in order to plan, coordinate and control the complex and diverse activities of modern industrial and commercial projects" (Zhang).

A faulty communication between these parts is a major failure cause in implementing information systems (i.e. between IT specialists and users or IT specialists and university management). Communication means not only sharing information between the project team but also communicating to the whole organization the results and the goals in each implementation stage.

The communication effort should be done in a regular basis during the implementation phase (Esteves et al). In order to successfully accomplish the decision to implement an ERP system, the effective project management comes into play to plan, coordinate and control such an intricate project (Yingjie).

26 Partnership During the implementation phase there are different partners involved such as consultants and software and hardware vendors. An adequate partnership between them will ease achievement of the goals defined (Esteves). The project leadership must engender trust and avoid attrition and unnecessary competition among members.

27 Scope Management

28 Leadership
This factor is related with concerns of project goals clarification and their congruence with the organizational mission and strategic goals. This includes both scope definition and subsequent scope control. Some components of this factor are: scope of business processes and business units involved, ERP functionality implemented, technology to be replaced/upgraded/integrated, and exchange of data. (Esteves et al.). Avoid Scope creep, which is clearly delineating and effectively limiting the scope of the project. While new functionality shouldn't be rejected outright, hard decisions have to be made to keep the project from careening out of proportion (Swartz). When there are unrealistic expectations from the ERP, poor estimation of its scope and size, it creates a mess and the realistic goals are lost. (Shruti)

Effective leadership is critical. The project lead can be considered to be the team leader or project champion for the CM project at this university. This is an additional recommended CSF for a successful ERP implementation. The Project leader needs leadership skills and respect of project members and university administration (Swartz et al). The single most important attribute of this key individual is the ability to efficiently and effectively run a large project, not loyalty to the university. Broad-based, consensus decision-making doesn't generally work on ERP projects (Swartz et al.).

\subsection{ERP-The Concept}

ERP attempts to integrate all departments and functions across the organization onto a single computer system that can serve all those different departments' particular needs. Each department typically has its own computer system configured for the particular ways that the department does its work. But ERP combines them into an integrated software program so that the various departments can more easily share information and communicate with each other. A major difference between ERP systems and traditional information systems comes from the integrated nature of ERP applications. Implementing an ERP system causes dramatic changes that need to be carefully administrated to reap the advantages of an ERP solution (Zairi et. al, 2001).

At the core of this enterprise software system is a central database. This database draws data from and feeds data into modular applications that operate on a common computing platform. This helps to standardize business processes and data definitions into a unified environment with a single unified software program divided into software modules that roughly approximate the old standalone systems. An ERP system "creates a single version of the truth" (Swartz et. al, 2001), because everyone drinks from the same well.

\subsection{Challenges}

ERP can play a crucial role in streamlining the whole educational system. Exploring the technological approach 
to education and integrating students, staff, sponsors and management becomes essential for today's fast growing educational environment. The myriad challenges that afflict a modern campus include but are not limited to the following:

"Difficulty in accessing information from paper files, improper means of exchanging information between various departments, lack of interconnection between departments, difficulty in keeping the records of students and staff error free and up-to-date, wastage of hundreds of hours by staff each month manually entering information or performing administrative tasks that could be handled automatically such as evaluations and generating results, lack of accuracy in maintaining the financial records such as fees, salary and expenses, lack of automation in calculating fee balances or finding fee defaulters, lack of automation for computing the staff's salary, lack of easy means or quick way to access old records, administrators spending too much time in creating time-tables and in assigning adjuncts, lack of means to provide employers and sponsors fast access to student records (Maheshwari et al, 2011)".

\subsection{Failure Probabilities}

Deployment of ERP entails significant risks mostly because of its complexity. The complexity presupposes that it has a high probability of failure as captured in the bulleted information below:

An unsuccessful ERP project can bankrupt a firm, as happened to FoxMeyer Drug Company (Tsai et. al., 2010).

Failure rates for ERP implementations are estimated to range between 50-90\%, depending upon the research used.

The Meta Group reports that as many as $70 \%$ or 7 out of 10 ERP projects end in failure, which is two and half times the industry average.

A Computer Associates survey of 886 managers reports $44 \%$ of ERP projects lose $\$ 1$ million per year, 35\% lose $\$ 5$ million per year, and 21\% lose $\$ 11$ million per year (Maheshwari et al, 2011).

\subsection{Costs Risks}

The most measured subset of costs is the initial software development efforts while the most uncertain (and often the largest) cost is long-term maintenance and training (Hubbard, 2009)

Escalating costs is another serious risk factor as exemplified below:

- International Data Group (IDG) investigated and disclosed that global expenditure on ERP systems climbed up with yearly increasing rate of 13.5\% between 2001 and 2006, and hit at $\$ 187$ billion in 2006 (Singhal et al, 2011).

- Expenditures are estimated to range between approximately $6 \%$ of the annual revenue for a large organization to up to $50 \%$ for small firms. In addition, as implementation costs rise, so does the chance of an implementation failure.

- In the United States alone, it is expected that higher education's collective investment in vendor-supplied enterprise administrative systems, modified versions of the standard ERP systems, may exceed $\$ 5$ billion to date, placing it among the most significant information technology (IT) investments of any kind (EDUCAUSE Center for Applied Research (ECAR), 2002).

- American Universities often spend in excess of $\$ 20$ million each to implement modern enterprise resource planning (ERP) projects that can take two, three, or more years to implement (Swartz et al, 2001). For example, Georgetown University (30 000) spent nearly $\$ 60$ million on a campus wide ERP initiative using PeopleSoft (Singhal et al., 2011).

\subsection{Success Stories}

The ERP story is not always a litany of failures. Below are a few of the many success stories that inspire institutions to hop on the train to the promise land of easy campus management.

Louisiana State University (45 000) implemented an award winning ERP system 1996, using Lotus Domino Notes. The University of Nebraska-Lincoln (22 000) successfully implemented an ERP system using Talisman. Gaska reports that the University of Houston (5 000) successfully implemented an ERP system in 1995 using PeopleSoft. Gaska says Florida Southern College (2 500) successfully used ERP software using Jenzabar

From above, it can be garnered that even though ERP deployment is a high risk venture, success can result in tangible and quantifiable benefits (Table 2). 
Table 2. Educause Quarterly \#2, 2001

\begin{tabular}{lcc}
\hline Description & Before & After \\
\hline Reduction in paper forms & N.A. & $\begin{array}{c}\text { (5,200 fewer forms } \\
\text { processed }\end{array}$ \\
Duration of monthly closing & 10 days & 4 days \\
Duration of semiannual closing & 4.5 months & 2 months \\
Availability of budget reports & Hardcopy monthly & Available online daily \\
Online access & 315 users & 1,645 users \\
Creation of account codes & Manual & Automatic \\
Alerts & 0 & 16 \\
Approval process & Manual & Automatic \\
Online requisitions & 775 & 11,400 \\
Paper requisitions & 12,973 & 4,323 \\
Online receipts & 0 & 6054 \\
Supply chain forms & N.A. & Eliminated 21 paper forms \\
Performance metrics & N.A. & Weekly \\
Policies and procedures & 30 & Desktop manuals and online \\
Days between letter-of-credit draw downs & Inconsistent and undocumented & 7 \\
\hline
\end{tabular}

\section{Taming the ERP Animal}

A process that has that many positive attributes but carries with it the risks of cost and schedule overruns as well as dreadfully low-success rate figures is necessarily a complex one.

\subsection{CSF Interactions and Relationships}

The main reason for the complexity of an ERP implementation process is the vast array of variables encountered in the planning, execution and monitoring process. The complexity is further magnified by the overwhelming number of interactions and relationships between the variables. This complex exercise can only be managed using tried and tested project management principles. It is both interesting and significant that the first six out of sixteen technology factors associated with software disasters are specific failures in the domains of project management, and three of the other technology deficiencies can be indirectly assigned to poor project management practices (Alleman, 2002).

\subsection{Grouping CSFs}

A compiled list of CSFs from other research work is shown in Table 3. Figure 1 is a graphic of the 28 unique CSFs identified by this paper (Frimpon, 2012). This number is very large for any software process. With such a large number there is the likelihood that many may have conflicting objectives. Therefore, it is helpful to bring some structure into the process by placing the possibly conflicting CSFs into separate groups where they may together help achieve a sub-objective of the main ERP objective of a successful implementation. Grouping criteria can help the process of checking whether the set of criteria selected is appropriate to the problem, can ease the process of calculating criteria weights in some methods, and can facilitate the emergence of higher level views of the issues (UK DTLR, 2001). In this paper, the criteria are the CSFs. A role is defined as a group of CSFs identified and put together for the purpose of achieving a sub-objective. Thus, roles are sets created to hold specific CSFs that help the attainment of the main objective. In this structuring exercise, the CSFs are placed in roles according to the following criteria: (Bullen et al., 1995)

1) Function: Identify the CSFs necessary to achieve the goals and objectives.

2) Best measure: Many other CSFs can be measures of the role but this CSF is the best or among the best.

In addition, we make the simplifying assumption that the CSFs in different roles have no interactions. Using simple set theory notation; for any pair of CSFs,

$$
\left(C S F_{i} \cap C S F_{j}\right)=\varnothing ; i \in \text { role } I, \text { and } j \in \text { role } J, I \neq J
$$


Table 3. Counts of CSFs identified by different papers

\begin{tabular}{|c|c|c|c|c|c|c|}
\hline $\begin{array}{l}\text { \# of } \\
\text { CSFs } \\
=\end{array}$ & 10 & 11 & 11 & 20 & 26 & 28 \\
\hline $\begin{array}{l}\text { Paper } \\
=\end{array}$ & Sumner et al. & Shanks et al. & NAH et al. & $\begin{array}{l}\text { Esteves-Sousa } \\
\text { et al. }\end{array}$ & FINNEY et al. & Frimpon et. al. \\
\hline 1 & Mgmt. support, & $\begin{array}{l}\text { Top mgmt. } \\
\text { support }\end{array}$ & $\begin{array}{l}\text { Appropriate } \\
\text { business and } \\
\text { information } \\
\text { technology } \\
\text { legacy systems }\end{array}$ & $\begin{array}{l}\text { Sustained mgmt. } \\
\text { support }\end{array}$ & $\begin{array}{l}\text { Top mgmt. } \\
\text { commitment and } \\
\text { support }\end{array}$ & Discipline \\
\hline 2 & $\begin{array}{l}\text { re-design of } \\
\text { business } \\
\text { processes, }\end{array}$ & $\begin{array}{l}\text { External } \\
\text { expertise }\end{array}$ & $\begin{array}{l}\text { Business plan } \\
\text { and vision }\end{array}$ & $\begin{array}{l}\text { Effective } \\
\text { organizational } \\
\text { change mgmt. }\end{array}$ & Change mgmt. & $\begin{array}{l}\text { Education and } \\
\text { Training }\end{array}$ \\
\hline 3 & $\begin{array}{l}\text { Training and } \\
\text { re-skilling, }\end{array}$ & $\begin{array}{l}\text { Balanced } \\
\text { project team }\end{array}$ & $\begin{array}{l}\text { Business process } \\
\text { reengineering } \\
\text { (BPR) }\end{array}$ & $\begin{array}{l}\text { Good project } \\
\text { scope mgmt. }\end{array}$ & $\begin{array}{l}\text { BPR and software } \\
\text { configuration }\end{array}$ & $\begin{array}{l}\text { Organizational } \\
\text { Culture }\end{array}$ \\
\hline 4 & $\begin{array}{l}\text { Re-design of } \\
\text { business } \\
\text { processes, }\end{array}$ & $\begin{array}{l}\text { Data } \\
\text { accuracy }\end{array}$ & $\begin{array}{l}\text { Change mgmt. } \\
\text { culture and } \\
\text { program }\end{array}$ & $\begin{array}{l}\text { Adequate project } \\
\text { team composition }\end{array}$ & $\begin{array}{l}\text { Training and job } \\
\text { redesign }\end{array}$ & $\begin{array}{l}\text { Project } \\
\text { Champion }\end{array}$ \\
\hline 5 & $\begin{array}{l}\text { External } \\
\text { consultants, }\end{array}$ & Clear goals & Communication. & $\begin{array}{l}\text { Comprehensive } \\
\text { business process } \\
\text { reengineering }\end{array}$ & $\begin{array}{l}\text { Project team: the } \\
\text { best and brightest }\end{array}$ & Commitment \\
\hline 6 & $\begin{array}{l}\text { Mgmt. } \\
\text { structure, }\end{array}$ & $\begin{array}{l}\text { Project } \\
\text { mgmt. }\end{array}$ & $\begin{array}{l}\text { ERP teamwork } \\
\text { and composition }\end{array}$ & $\begin{array}{l}\text { Adequate project } \\
\text { champion role }\end{array}$ & $\begin{array}{l}\text { Implementation } \\
\text { strategy and } \\
\text { timeframe }\end{array}$ & $\begin{array}{l}\text { Needs } \\
\text { assessment }\end{array}$ \\
\hline 7 & $\begin{array}{l}\text { Discipline and } \\
\text { standardization }\end{array}$ & $\begin{array}{l}\text { Change } \\
\text { mgmt. }\end{array}$ & $\begin{array}{l}\text { Monitoring and } \\
\text { evaluation of } \\
\text { performance }\end{array}$ & $\begin{array}{l}\text { User involvement } \\
\text { and participation }\end{array}$ & $\begin{array}{l}\text { Consultant } \\
\text { selection and } \\
\text { relationship }\end{array}$ & $\begin{array}{l}\text { Team } \\
\text { Composition }\end{array}$ \\
\hline 8 & $\begin{array}{l}\text { Effective } \\
\text { communication }\end{array}$ & $\begin{array}{l}\text { Education } \\
\text { and training }\end{array}$ & $\begin{array}{l}\text { Project } \\
\text { champion }\end{array}$ & $\begin{array}{l}\text { Trust between } \\
\text { partners }\end{array}$ & $\begin{array}{l}\text { Visioning and } \\
\text { planning }\end{array}$ & $\begin{array}{l}\text { System } \\
\text { Configuration }\end{array}$ \\
\hline 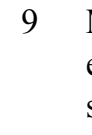 & $\begin{array}{l}\text { Maintaining } \\
\text { excellent } \\
\text { staffing }\end{array}$ & $\begin{array}{l}\text { Best people } \\
\text { full-time }\end{array}$ & Project mgmt. & $\begin{array}{l}\text { Adequate ERP } \\
\text { implementation } \\
\text { strategy }\end{array}$ & Balanced team & $\begin{array}{l}\text { Consultant } \\
\text { Support }\end{array}$ \\
\hline $\begin{aligned} 10 & \\
& \\
& \\
& \\
& 1\end{aligned}$ & $\begin{array}{l}\text { Avoiding } \\
\text { attempts at } \\
\text { software } \\
\text { modification. }\end{array}$ & $\begin{array}{l}\text { Minimal } \\
\text { customization }\end{array}$ & $\begin{array}{l}\text { Software } \\
\text { development, } \\
\text { testing, and } \\
\text { troubleshooting }\end{array}$ & $\begin{array}{l}\text { Avoid } \\
\text { customization }\end{array}$ & Project champion & Coordination \\
\hline 11 & & $\begin{array}{l}\text { Presence of a } \\
\text { champion }\end{array}$ & $\begin{array}{l}\text { Top mgmt. } \\
\text { support }\end{array}$ & $\begin{array}{l}\text { Adequate ERP } \\
\text { version }\end{array}$ & $\begin{array}{l}\text { Communication. } \\
\text { plan }\end{array}$ & Customization \\
\hline 12 & & & & $\begin{array}{l}\text { Dedicated staff } \\
\text { and consultants }\end{array}$ & IT infrastructure & Data Accuracy \\
\hline 13 & & & & $\begin{array}{l}\text { Strong comm. } \\
\text { inwards and } \\
\text { outwards }\end{array}$ & $\begin{array}{l}\text { Managing cultural } \\
\text { change }\end{array}$ & $\begin{array}{l}\text { Decision } \\
\text { Delegation }\end{array}$ \\
\hline 14 & & & & $\begin{array}{l}\text { Formalized project } \\
\text { plan/schedule }\end{array}$ & $\begin{array}{l}\text { Post-implementation } \\
\text { evaluation }\end{array}$ & Formalized plan \\
\hline 15 & & & & $\begin{array}{l}\text { Adequate training } \\
\text { program }\end{array}$ & Selection of ERP & $\begin{array}{l}\text { Hardware and } \\
\text { Software }\end{array}$ \\
\hline 16 & & & & $\begin{array}{l}\text { Preventive trouble } \\
\text { shooting }\end{array}$ & $\begin{array}{l}\text { Team morale and } \\
\text { motivation }\end{array}$ & Leadership \\
\hline 17 & & & & Appropriate usage & Vanilla ERP & Partnership \\
\hline
\end{tabular}




\begin{tabular}{|c|c|c|c|}
\hline & of consultants & & \\
\hline 18 & $\begin{array}{l}\text { Empowered } \\
\text { decision-makers }\end{array}$ & Project mgmt. & PME \\
\hline 19 & $\begin{array}{l}\text { Adequate software } \\
\text { configuration }\end{array}$ & $\begin{array}{l}\text { Troubleshooting / } \\
\text { crises mgmt. }\end{array}$ & $\begin{array}{l}\text { Scope } \\
\text { management }\end{array}$ \\
\hline 20 & $\begin{array}{l}\text { Legacy systems } \\
\text { knowledge }\end{array}$ & $\begin{array}{l}\text { Legacy system } \\
\text { consideration }\end{array}$ & Staffing \\
\hline 21 & & $\begin{array}{l}\text { Data conversion } \\
\text { and integrity }\end{array}$ & Standardization \\
\hline 22 & & System testing & ERP Strategy \\
\hline 23 & & Client consultation & $\begin{array}{l}\text { Top mgmt. } \\
\text { Support }\end{array}$ \\
\hline 24 & & $\begin{array}{l}\text { Project cost } \\
\text { planning and mgmt. }\end{array}$ & $\begin{array}{l}\text { Testing and } \\
\text { Troubleshooting }\end{array}$ \\
\hline 25 & & $\begin{array}{l}\text { Build a business } \\
\text { case }\end{array}$ & $\begin{array}{l}\text { User } \\
\text { Involvement }\end{array}$ \\
\hline 26 & & $\begin{array}{l}\text { Empowered } \\
\text { decision makers }\end{array}$ & Vendor Support \\
\hline 27 & & & Vision and Goals \\
\hline 28 & & & ERP version \\
\hline
\end{tabular}

Table shows that progressively large numbers of CSFs can be incorporated in a scalable ERP model.

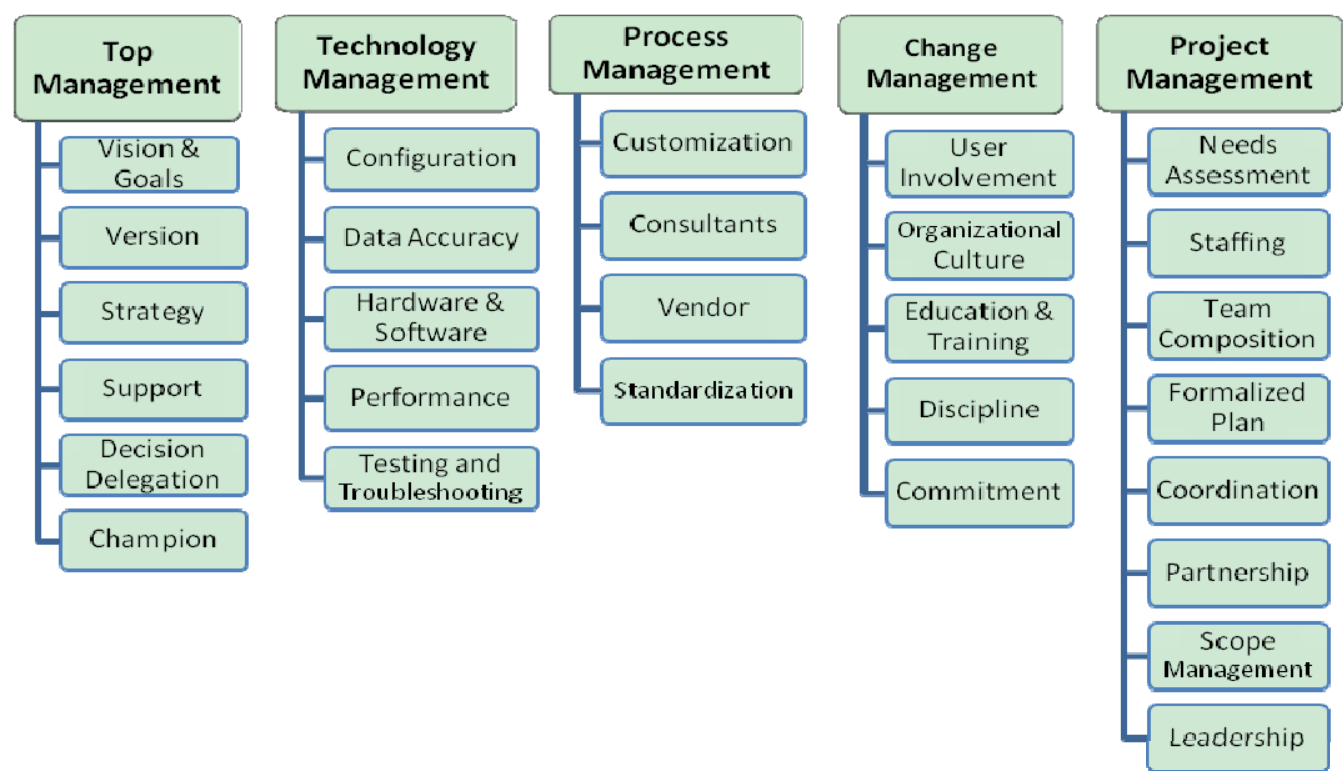

Figure 1. Roles with their associated CSFs

Figure 1 shows the roles with their full complement of Critical Success Factors. In this model, interactions between CSFs take place only in the roles. In subsequent iterations, it is plausible to come up with inter-role interactions such that the CSFs in a role can influence the others in a different role (Frimpon, 2012).

\subsection{Pair wise Comparisons}

Given that "n" = number of attributes, the pairwise comparisons formula

$$
n(n-1) / 2
$$


allows us to deal with the Combinatorics problem of comparing CSFs two at a time.

Table 4 shows the results of algebraic calculations to determine the number of Pairwise comparisons "between the CSFs in their respective roles", and "between the roles" themselves. The Excel "Combin function" accomplishes the same. Note: $\mathrm{n}=$ number of CSFs.

The dramatic reduction of 299 (378-79) pairwise comparisons is due to the fact that there are no interactions between CSFs in different roles as outlined in (A) above.

Table 4. Pairwise Comparisons Calculations

\begin{tabular}{lcc}
\hline \multicolumn{2}{c}{ Results of Pairwise Comparisons Calculations between the CSFs in their respective roles } \\
\hline Role & $\mathrm{n}$ & $\mathrm{n}(\mathrm{n}-1) / 2$ \\
Top Mgmt & 6 & 15 \\
Technology Mgmt & 5 & 10 \\
Process Mgmt & 4 & 6 \\
Change Mgmt & 5 & 10 \\
Project Mgmt & 8 & 28 \\
Totals & 28 & 69 \\
\hline \multicolumn{2}{c}{} \\
\hline Role & $\mathrm{n}$ & $\mathrm{n}(\mathrm{n}-1) / 2$ \\
Number of Roles & 5 & 10 \\
Total Comparisons & Pairwise Comparisons between the Roles \\
\hline \multicolumn{2}{c}{$(69+10)=79$} \\
\hline Role & Pairwise Comparisons between the CSFs altogether \\
Total number of CSFs & $\mathrm{n}$ & $\mathrm{n}(\mathrm{n}-1) / 2$ \\
& 28 & 378 \\
\hline
\end{tabular}

\subsection{Sensitivity Analysis}

Table 5 shows how the structured model behaves under perturbations. The max values are obtained after additions to the role with the largest number of CSFs, Project management, and the min values are obtained after additions to the role with the smallest number of CSFs, Process management. The unstructured model explodes after additions, but the structured one increases less dramatically, and is thus computationally less intensive. The rate of change in the number of CSFs on addition of CSFs is captured by the "gradient" column. The gradient value of 29 for the unstructured model is much higher than the 9 (or even 5) for the structured one. This again shows the relatively minimal sensitivity to changes in the case of the structured model as against the unstructured one.

Table 5. Model Behavior under minor Perturbations

\begin{tabular}{lccccc}
\hline Table 5/ & $\begin{array}{c}\text { Current \# of } \\
\text { Pairwise } \\
\text { Comparisons (PCs) }\end{array}$ & $\begin{array}{c}\text { PCs after 1 } \\
\text { Additional CSF }\end{array}$ & $\begin{array}{c}\text { PCs after 2 } \\
\text { Additional CSF }\end{array}$ & $\begin{array}{c}\text { PCs after 3 } \\
\text { Additional CSF }\end{array}$ & Gradient \\
\hline Structured (Min) & 79 & 83 & 88 & 94 & 5 \\
Structured (Max) & 79 & 87 & 96 & 106 & 9 \\
Unstructured & 378 & 406 & 435 & 465 & 29 \\
\hline
\end{tabular}

\section{Project Management Principles}

\subsection{PM Tools and Techniques}

A complex process with an overabundance of influencing factors such as an ERP implementation needs the structure and organization that can only be provided by the tools and techniques of project management. Project management is the application of knowledge, skills, tools, and techniques to manage project activities. Managing 
an ERP project is not the same as managing a large scale IT project. IT projects emphasize requirements elicitation, detailed planning, and execution of identified tasks, followed by end-to-end delivery of business functionality. Even though this project methodology faces difficulty when scaled to larger projects, applying it to ERP projects creates further difficulties. The project management method used with ERP deployments must provide adaptability and agility to support these evolutionary processes and technologies (Alleman, 2002).

ERP implementation projects need to be controlled. ERP implementation system is significantly different from a traditional system implementation (Hatami et. al, 2011).

An objective of this research is to simplify the ERP implementation process. To achieve this, the implementation should be carried out using simple but sound project management principles. A simple PM tool such as a Program Evaluation and Review Technique (PERT) diagram helps structure the sequencing of the CFSs. Among the many advantages of a PERT diagram is that it

- forces managers to organize

- $\quad$ provides a graphic display of activities

Project management activities start from the first stage of the ERP implementation to the end. Thus, an effective project management is crucial (Hatami et. al, 2011).

ERP is a technological process but managing the human component is the key for success. What project management will do for the ERP implementation is to provide a system for managing this human component such as providing a basis for better decision making. A Deloitte and Touché survey of 164 professionals shows this clearly in Table 6 (Maheshwari, 2011).

Table 6. ERP Failure Source Distribution

\begin{tabular}{lc}
\hline FAILURE SOURCE & Frequency (\%) \\
\hline People & $62 \%$ \\
Business Process & $16 \%$ \\
Technology & $12 \%$ \\
Others & $10 \%$ \\
Total & $100 \%$ \\
\hline
\end{tabular}

Ultimately, it is people who will make things happen and make things work, not the methodology.

\subsection{Algorithms}

Table 7 shows some very simplified renditions of PERT diagrams to map the CSFs forward. Top Management, Technology Management and Process Management roles have CSFs that can be scheduled using simple PERT visualizations. The diagrams in Change Management and Project Management roles are more of "Influence diagrams than PERT" diagrams. The CSFs are measurable but they are not activities to be scheduled. Rather they are intrinsic attributes that need to be ready before the ERP process begins.

Table 7. Suggested Algorithms for Sequencing CSFs

\begin{tabular}{ll}
\hline & Top Management Role \\
\hline 1 & Articulate the Goals and Vision \\
2 & Approve the Version \\
3 & Outline implementation strategy \\
4 & Support in cash and kind \\
5 & Delegate the decisions \\
6 & Champion / advocate \\
\hline & Below are suggested sequencing of the tasks for Top Management, Technology Management and \\
& Process Management roles in the deployment of an ERP. The PERT diagrams clearly delineate the \\
\hline
\end{tabular}


paths. The use of a PERT diagram, if even for visualization only can bring some clarity to the process.

Top Management PERT

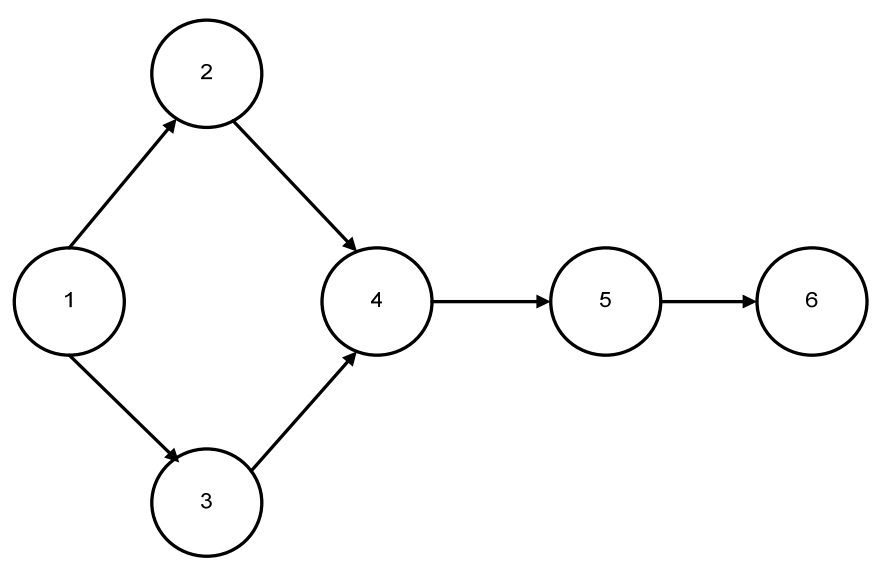

\section{Technology Management Role}

1. Hardware and software

2. Data migration

3. Configure system

4. Monitor system

5. Test/troubleshoot system

Technology Management PERT

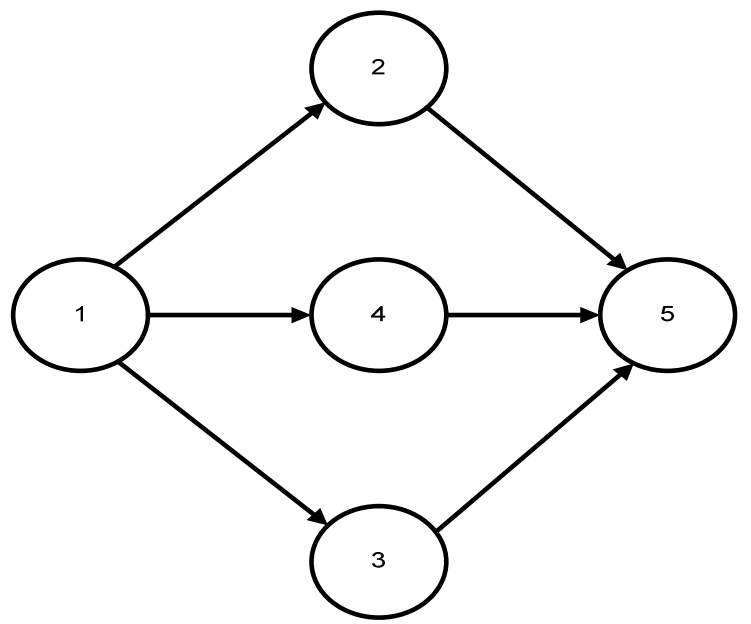

\section{Process Management Role}

1. Consultant support

2. Vendor input

3. Standardization

4. Customization

Process Management PERT 


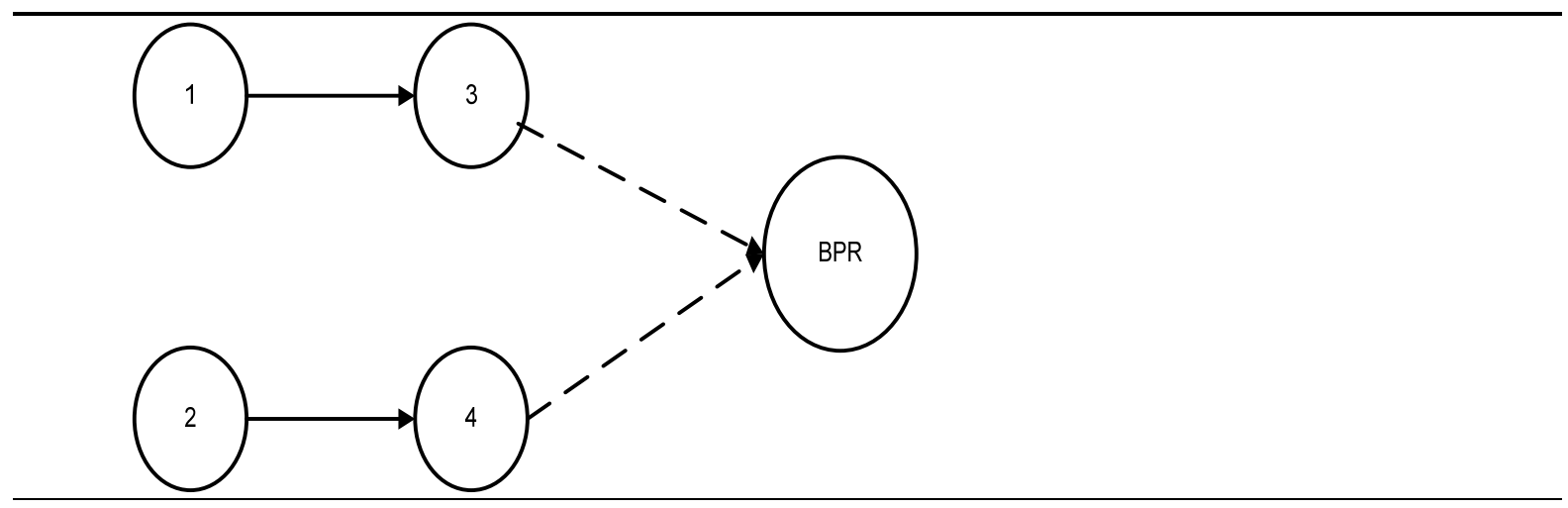

\section{Change Management Role}

1. User Involvement

2. Organizational Culture

3. Education and Training

4. Discipline

5. Commitment

The CSFs in Change management are not active tasks that can be scheduled or sequenced one ahead of the other. They are more of behaviors or beliefs that should be communicated appropriately for a successful exercise. That is the rationale for using broken circles to distinguish them from the others.

Change Management PERT

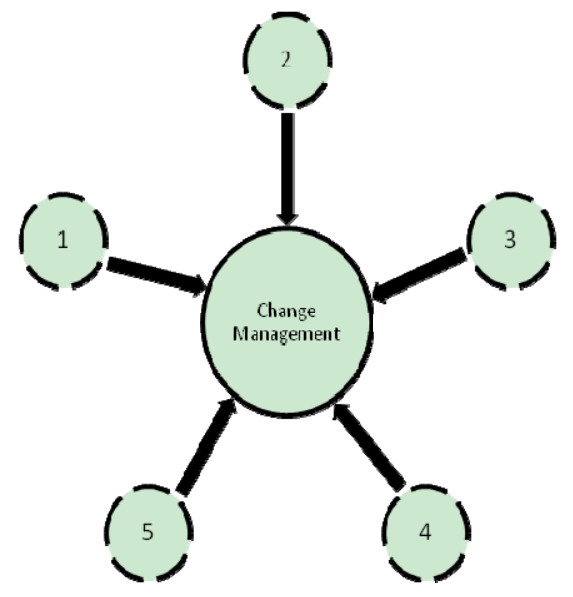

\section{Project Management Role}

1. Needs assessment

2. Competent team

3. Heterogeneous team

4. Formalize plan

5. Coordination

6. Partnership

7. Scope management 


\section{Exhibit leadership}

Except perhaps for needs assessment, the CSFs here can't mostly be scheduled or sequenced one ahead of the other. But the project management team must possess these attributes or/and find a way of managing them.

Project Management PERT

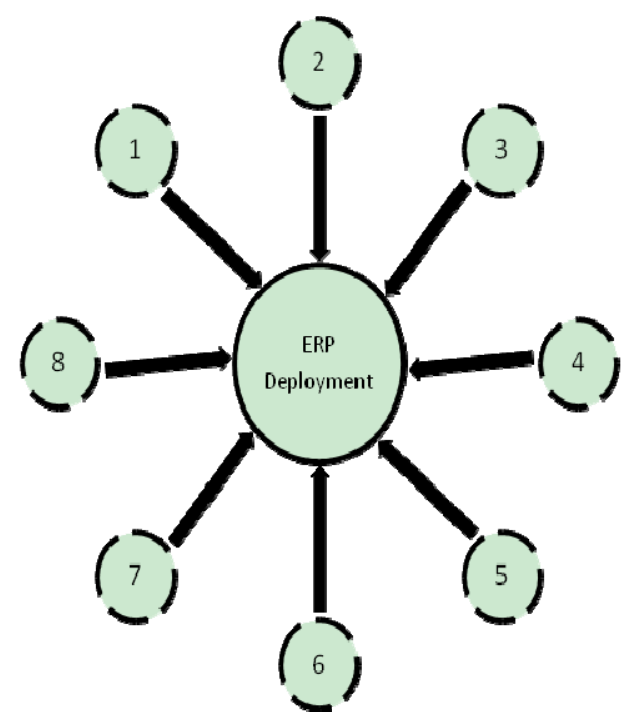

\section{A Project-Managed ERP Implementation}

Good project planning is a critical step in the ERP process and must be carried out diligently. Thorough planning not only provides a blueprint for the implementation, but also becomes a most important risk mitigation tool (Cornelius, 2007).

The PERT tool can be used to sequence the ERP process as in the suggested implementation algorithms below (Cornelius, 2007):

1) A project scope document

2) A project timeline and project schedule

3) A project organization,

4) A final project budget

5) A project risk analysis

6) A project communication plan

7) A change impact analysis

8) A training plan

9) A scope management process

10) A metrics tracking and reporting

The roles are the pillars that shoulder the burden of the implementation of the ERP process. Figure 2 depicts the configuration of the ERP process. A weakness in any of the pillars can result in a failure. On the other hand, all the pillars have to be managed well to result in a successful implementation (Frimpon, 2012). A targeted process properly managed using tried and tested project management principles is what will allow a process to not become part of the statistics of failure that dot the ERP landscape. 


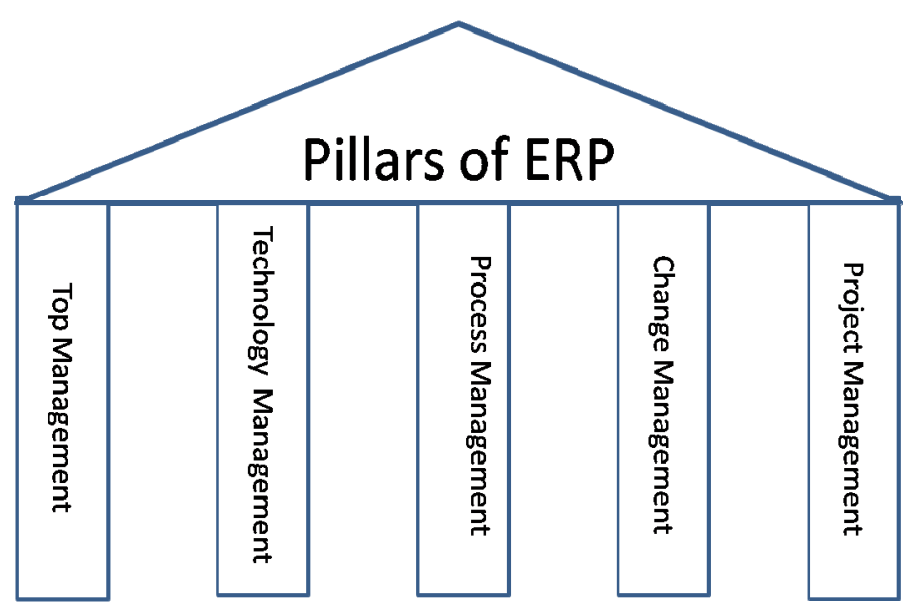

Figure 2. Pillars of Successful ERP Implementations

This graphic captures the holistic idea of an ERP implementation process. A sub-optimization in any of the pillars will result in a failure as has been chronicled in many papers. When the pillars are sturdy, then a successful implementation is assured (Frimpon, 2012).

\section{Conclusion}

ERP is still in its embryonic stages having been around only since 1990. Literature on ERP implementations in the third world in the ERP-knowledge domain is not the best. In particular, Africa is still virgin territory when it comes to its deployment. There is not much record of previous research that interested organizations such as colleges and universities can use to map their path towards an assured success.

This study defines a re-structured CSFs "role" model for ERP implementations. As clearly stated in the abstract, an objective of the paper is to suggest the use of Project management 101 principles to be used to manage the most complex of software deployments such as an ERP. The tendency is to go for very complex models and approaches due to the notoriety of the process, but it is being espoused here that a simpler modeling approach should be more helpful. The use of PERT diagrams, if even for visualization only can bring some clarity to the process. Another objective is to postulate that there should be no whittling down of factors out of convenience or because of the difficulty of handling them all. A scalable model does not have to be limited to a Pareto few. In effect, modern computing can acknowledge the existence of the Pareto phenomenon but it has the tools and capabilities to incorporate and control all identified attributes especially when it comes to software deployment. As seen in the sensitivity analysis table (Table 5 in appendix), the model is scalable due to the partitioning, and the addition of a few more CSFs will not cause it to explode to the point of being computationally unstable.

\subsection{Limitations and Future Research}

The model certainly is expected to go through a few more iterations before it comes of age. Metrics should be developed to measure the Roles and their associated CSFs in order to be better able to quantify the implementation process. A good methodology like Analytic Hierarchy Process (AHP) by Saaty can be used to determine the weights of the attributes instead of number of citations as used by certain authors. Figure 3 is a decision-analytic diagram that can be used as a template for determining the weights in a next iteration of this model.

If there are dependencies between the Critical Success Factors, as is most likely, then a modeling approach like Analytical Network Process (ANP) also by Saaty should be used to determine and calibrate the weights to further enhance the accuracy of the model.

Recently Cloud computing has become the buzzword and it is having applications in many domains. Researchers have already started applying cloud computing in ERP implementations of Higher education (Goel et. al, 2011). The Cloud works on the principle of economies of scale and there can be enormous cost savings as a result. This new initiative can be explored because it should have great utility for resource-starved organizations like those in Africa.

The decision-analytic hierarchy above is a model that contains many attributes and can accommodate even more if the need arises. 


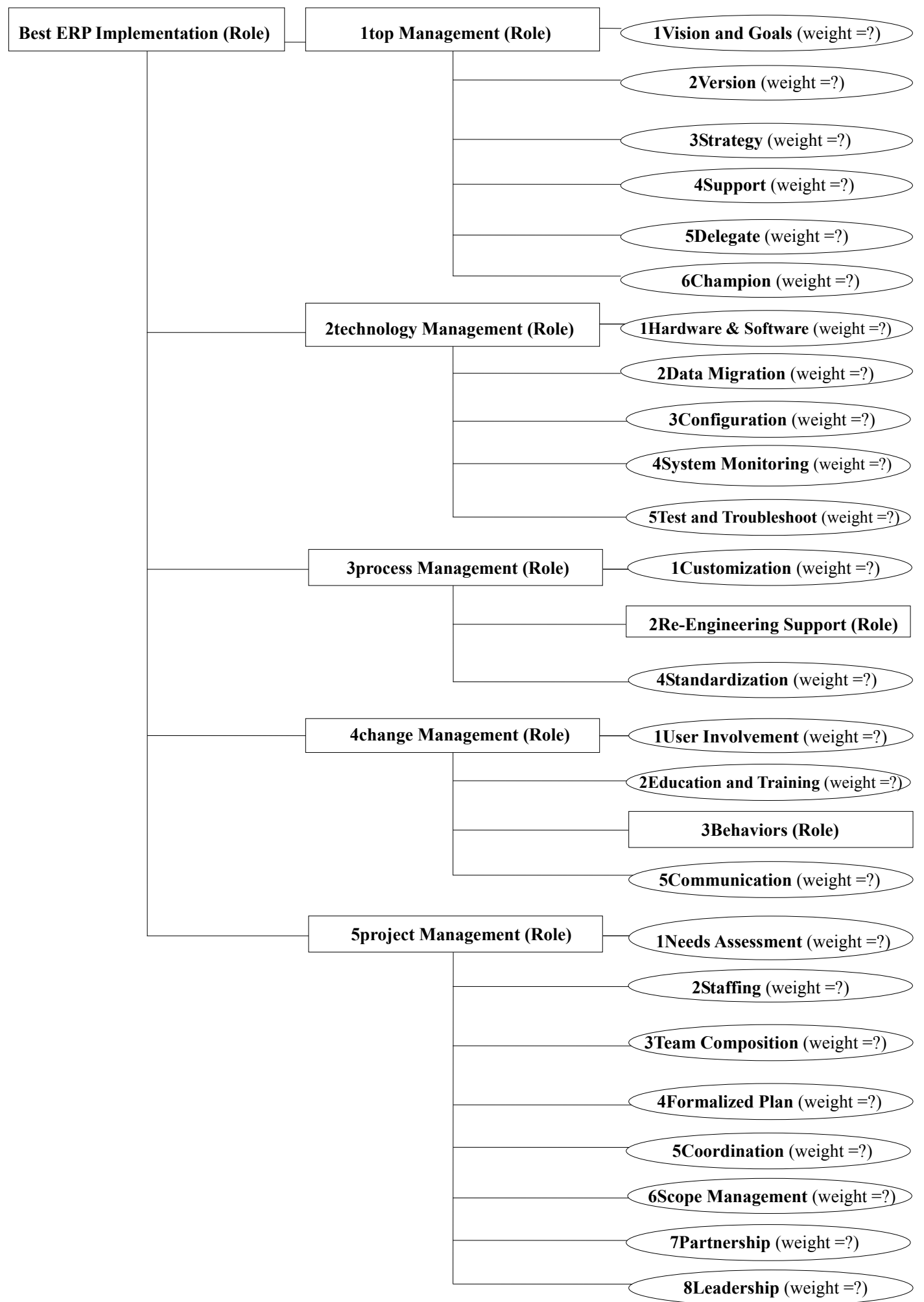

Figure 3. Model to Quantify an ERP Implementation Process

\section{References}

Alleman, Glen. (2002). Agile Project Management Methods for ERP: How to Apply Agile Processes to Complex COTS Projects and Live to Tell About It. In Don Wells, \& Laurie Williams (eds.), Extreme Programming and Agile Methods: XP/Agile Universe 2002 (pp. 70-88). 
Al-Mudimigh, A., Zairi, A., \& Al-Mashari, M. (2001). ERP software implementation: an integrative framework.

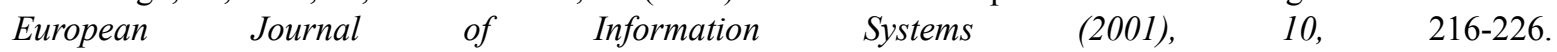
http://dx.doi.org/10.1057/palgrave.ejis.3000406

Ansarinejad, A., Amalnick, M., Ghadamyari, M., Ansarinejad, S., \& Hatami-Shirkouhi, L. (2011). Evaluating the Critical Success Factors in ERP Implementation using Fuzzy AHP Approach. International Journal of Academic Research, 3(1), January, 2011, Part I.

Barker, T., \& Frolick, M. N. (2003). ERP implementation failure: A case study. Information Systems Management, 20(4), 43-49. http://dx.doi.org/10.1201/1078/43647.20.4.20030901/77292.7

Bologa, A., Muntean, M., Sabau, G., \& Scorta, J. (2009). Higher Education ERPs: Implementation Factors and Their Interdependencies. Wseas Transactions on Computers, 8(4), 651-660.

Bullen, C. V. (1995). Productivity CSFs for Knowledge Workers. Information Strategy: The Executive's Journal, 12(1), 14

Cornelius, E. Seven Steps in the ERP Process. (2007). Collegiate Project Services. Retrieved from www.collegiateproject.com

Davis, M. J., \& Huang, Z. (2007). ERP in Higher Education: A Case Study of SAP and Campus Management. Issues in Information Systems, VIII(1), 120-126. Retrieved from http://iacis.org/iis/2007/Davis_Huang.pdf

Esteves-Sousa, J., \& Pastor-Collado, J. (2000). Towards The Unification of Critical Success Factors for ERP Implementations. 10th Annual Business Information Technology (BIT) 2000 Conference, Manchester.

Finney, S., \& Corbett, M. (2007). ERP implementation: a compilation and analysis of critical success factors. Business Process Management Journal, 13(3), 329-347. http://dx.doi.org/10.1108/14637150710752272

Francoise, O., Bourgault, M., \& Pellerin, R. (2009). ERP Implementation through Critical Success Factors' Management. Business Process Management Journal, 15(3), 371-394. http://dx.doi.org/10.1108/14637150910960620

Frimpon, M. (2012). A Re-Structuring of the Enterprise Resource Planning Implementation Process. International Journal of Business and Social Science, 3(1).

Fülöp, J. (2001). Introduction to Decision Making Methods. Laboratory of Operations Research and Decision Systems, Computer and Automation Institute, Hungarian Academy of Sciences.

Goel, S., Kiran, R., \& Garg, D. (2011). Impact of Cloud Computing on ERP implementations in Higher Education. International Journal of Advanced Computer Science and Applications, 2(6), 146-148.

Hubbard, D. (2007). How to Measure Anything. Retrieved from http://www.tacadvisory.com/teleconf/T070313A.pdf

Iskanius, P. (2009). The ERP Project Risk Assessment - A case study. Retrieved from http://www.iaeng.org/publication/WCE2009/WCE2009_pp752-756.pdf

Jafari, S. M., Osman, M. R., Yusuff, R. M., \& Tang, S. H. (2006). ERP Systems Implementation in Malaysia: The Importance of Critical Success Factors. International Journal of Engineering and Technology, 3(1), 125-131.

Lee, C., \& Lee, H. (2001). Factors affecting ERP Implementation systems in a Higher Education Institution. Retrieved from http://iacis.org/iis/2001/LEE207.PDF

Maheshwari, S. P., Singh, P., \& Tripathi, L. K. (2011). ERP Implementation in Educational Institutions: Challenges and Opportunities. Eighth AIMS International Conference on Management, January 1-4, 2011

Nah, F. F., Zuckweiler, K. M., \& Lau, J. L. (2003). ERP Implementation: Chief Information Officers' Perceptions of Critical Success Factors. International Journal of Human-Computer Interaction, 16(1), 5-22. http://dx.doi.org/10.1207/S15327590IJHC1601_2

Paula, K., \& Robert B. K. (2002). ERP Systems in Higher Education. ECAR (EDUCAUSE Center for Applied Research), 2002(22).

Saaty, T. (2008). Relative Measurement and Its Generalization in Decision Making. Why Pairwise Comparisons are Central in Mathematics for the Measurement of Intangible Factors: The Analytic Hierarchy/Network Process. RACSAM (Rev. R. Acad. Cien. Serie A. Mat.), 102(2), 251-318.

Shanks, G., Parr, G. A., Hu, B., Corbitt, B., Thanasankit, T., \& Seddon, P. (2000). Differences in Critical Success 
Factors in ERP Systems Implementation in Australia and China: A cultural analysis. Retrieved from http://aisel.aisnet.org/ecis2000/53/

Singhal, S., Tandon, P., \& Sharma, S. K. (2011). Critical Success Factors in Implementation of ERP in Education. International Journal of Contemporary Practices, 1(1).

Siriginidi, S. R. (2000). Enterprise resource planning: business needs and technologies. Industrial Management \& Data Systems, 100(2), 81-88. http://dx.doi.org/10.1108/02635570010286078

Swartz, D., \& Orgill, K. (2001). Higher Education ERP: Lessons Learned. Educause Quarterly, 24(2), 20-27.

Tsai, W., Chen, S., Hwang, E. T. Y., \& Hsu, J. (2010). A Study of the Impact of Business Process on the ERP System Effectiveness. International Journal of Business and Management, 5(9), 26-37.

Wei, C., Chien, C., \& Wang, M. J. (2003). An AHP-based approach to ERP system selection. Int. J. Production Economics, 96(2005), 47-62.

West, R., \& Diagle, S. L. (2004). Total Cost of Ownership (TCO): A Strategic Tool for ERP Planning and Implementation. Educause Center for Applied Research, 2004(1), 1-14.

Yingjie, J. (2005). Critical Success Factors in ERP Implementation in Finland. Education and Training, 2008(2001), 1-9.

Zhang, L., Lee, M. K. O., Zhang, Z., \& Banerjee. (2003). P. Critical Success Factors of Enterprise Resource Planning Systems Implementation Success in China. 36th Hawaii International Conference on System Sciences -2003 . 